\title{
Uusinko eväin uudelle vuosituhannelle?
}

Maa on saanut uuden hallituksen, ja hallitusneuvottelut tuottivat tavanomaisen hallitusohjelman. Koulutusta koskeva osa ei paljon lupaa, mutta ei se suuria uhkiakaan ennakoi. Selvimmät ja toiminnallisimmat lupaukset koskevat koko ikäluokan ilmaisen esiopetuksen aloittamista ensi vuoden syksystä ja ammattikorkeakoulua koskevan lainsäädännön uudistamista.

Niin monia taka-askeleita esiopetuksen säätäminen on ottanut, että jokohan nyt voisi uskoa Suomen jättävän esiopetuksen kehitysmaan asemansa taakseen. Sosiaali- ja koulutushallinto kenties käyvät kuitenkin vielä yhden (ratkaisevan) taistelun kuusivuotiaitten sieluista. Taistelu näyttää kääntyvän kouluhallinnon voitoksi, jos oppivelvollisuuden alaikärajaa alennetaan kuuteen vuoteen, niin kuin aikomus näyttää olevan. Melko uuden ammattikorkeakoululain uudistamisen motiivien tulkitsemiseen tarvitaan Delfoin oraakkelia. Kysymys voi olla yksinkertaisesti vanhakantaisen normittavan lain saattamisesta samaan ruotuun muiden koululakien kanssa, jotka ovat selviä virtaviivaisia puitelakeja. Tai sitten uudella lailla aiotaan säädellä vieläkin yksityiskohtaisemmin suhdetta yliopistoon. Kenties halutaan valmistella tietä akatemisoitumiseen, kaksijakoisen korkeakoulutuksen yhdentämiseen!

Y liopistoväkeä hiukan kylmää pahaenteinen toteamus rakenteellisen kehittämisen jatkamisesta ja säästyneiden varojen kohdentamisesta uudelleen. Laman alkaessa koulutuksen ja tutkimuksen kehittämissuunnitelmaan ilmestyneet sanat tiesivät pahimmillaan lähes 20 prosentin vähennystä yliopistojen perusrahoituksessa.

Koulutuspoliittiset avainkäsitteet hallitusohjelmassa ovat tietoyhteiskunta ja informaatioteknologia. Todetaan, että tietoyhteiskunnan tuloa tuetaan lainsäädännön avulla. Ohjelmassa tietoyhteiskunta käsitetään teknologian hallitsemaksi elämäntavaksi, ja kun 
samassa yhteydessä puhutaan sivistyksestä, sivistys nähdään teknologian läpäisemänä. Viestintäteknologia näyttää siirtyvän rengistä isännän paikalle, kun todetaan, että sähköistä asiointia ja julkisen sektorin toimintaa kehitetään tieto- ja viestintätekniikan tarjoamista mahdollisuuksista käsin. Poliitikon voisi kuvitella asettavan äänestäjänsä tarpeet ja toiveet etusijalle. Ohjelma lupaa tuoda tietoyhteiskunnan palvelut tasapuolisesti kaikkien ulottuville ja varmistaa eri politiikan lohkoilla $\mathrm{mm}$. alueellinen tasapaino ja yhteiskunnallinen tasa-arvo. Paljon luvattu, kun tiedämme, miten tietotekniikasta on tullut lisätekijä syrjäytymisen ja eriarvoisuuden aiheuttajana. Pörssiyhtiöiksi muuttuneiden puhelinlaitosten tekemät rajut hintojen korotukset verkon ja palvelimien käytöstä eivät ennusta hyvää.

I tsestään selvä toteamus ohjelmassa on, että ohjaavana periaatteena koulutuspolitiikassa tulee olla elinikäisen oppimisen ideologia Toivottavasti hallitus ryhtyy myös konkreettisiin toimiin koulutusjärjestelmän kehittämiseksi ideologian mukaisesti. Elinikäisen oppimisen komitean esitysten jatkotyöstäminen on kestänyt opetusministeriössä luvattoman kauan. Suuria mahdollisuuksia oikeaan suuntaan tarjoavat hallitusohjelman kirjaukset koulutuksen työelämäyhteyksien kehittämisestä, työssä oppimisen tärkeydestä, oppimisen osoittamisesta näytöillä ja huomion kiinnittäminen osaamisen hyödyntämiseen, jonka luen sillä tavalla, että irrallisesta tiedosta tai taitojen hallinnasta on siirryttävä toiminnallisten kompetenssien hankkimiseen.

Aikuiskoulutuksen tärkeyttä ohjelma perustelee osaamisen ylläpitämisellä ja liikkuvuuden edistämisellä. Irrallisena ja orpona lauseena todetaan, että hallitus vahvistaa vapaan sivistystyön edellytyksiä. Katsotaan!

Reijo Raivola

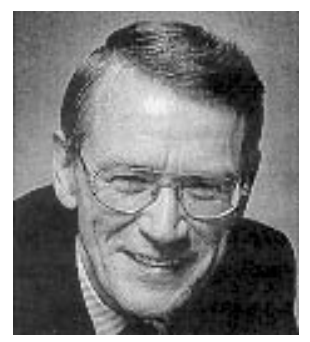

